\title{
High incidence of plasmid-mediated quinolone resistance genes among ciprofloxacin-resistant clinical isolates of Enterobacteriaceae at a tertiary care hospital in Puducherry, India
}

Thiyagarajan Yugendran, Belgode Narasimha Harish

Background: Plasmid-mediated quinolone resistance (PMQR) has received considerable attention recently. Data analysis in Jawaharlal Institute of Postgraduate Medical Education $\&$ Research (JIPMER) revealed $75 \%$ of the Enterobacteriaceae isolates to be ciprofloxacinresistant in 2012. Few reports regarding the prevalence of PMQR are available from India. Hence, the present study was carried out to ascertain the prevalence of PMQR genes among clinical isolates of ciprofloxacin-resistant Enterobacteriaceae in JIPMER. Methods: The study included 642 ciprofloxacin-resistant clinical Enterobacteriaceae isolates. JIPMER hospital's annual consumption data for fluoroquinolones were retrieved from the Department of Pharmacy. The test isolates were screened for the presence of $\operatorname{qnr} A, B, D$, $S$ and $\operatorname{aac}\left(6^{\prime}\right)-1 b$-cr genes. PMQR-positive isolates alone were tested for the presence of class I (int/1) and class II (int/2) integrons. Randomly selected PCR amplicons were sequenced and analysed using MEGA software. A total of 30 PMQR strains chosen at random were assessed for the transferability of the PMQR genes. Results: A majority of the strains exhibited high MIC values with 106 strains exhibiting MIC values ' $256 \mu \mathrm{g} / \mathrm{mL}$. The aac $\left(6^{\prime}\right)-I b$-cr gene had the highest prevalence at 64\% (414) while, qnrB and qnrS genes were present in 15\% (97) and 10\% (64) of the isolates respectively. None of the strains were positive for qnrA and qnrD. All PMQR-positive isolates were screened for class I (int/1) and class II (int/2) integrons. Class I integron was found to be predominant among the test isolates with a few of them carrying both the classes of integrons. Transferability of PMQR genes to transconjugants was identified. Conclusion: The incidence of PMQR genes in the tertiary-care setup of the JIPMER hospital was found to be high which could be probably due to the increased prescription of fluoroquinolones. Thus, there is a need for rational usage of fluoroquinolones. 
1 High incidence of plasmid-mediated quinolone resistance genes among ciprofloxacin2 resistant clinical isolates of Enterobacteriaceae at a tertiary care hospital in Puducherry, 3 India.

4 Thiyagarajan Yugendran ${ }^{1}$, Belgode Narasimha Harish ${ }^{1}$

51 - Department of Microbiology, Jawaharlal Institute of Post-graduate Medical Education and

6 Research, Puducherry, India

7 Corresponding Author:

8 Belgode Narasimha Harish

9 Senior Professor \& Head, Dept. of Microbiology, Jawaharlal Institute of Post-graduate Medical 10 Education and Research (An Institution of National Importance under the Ministry of Health \&

11 Family Welfare, Govt. of India), Dhanvantari Nagar, Puducherry - 605006, India

12 Email Address: drbnharish@gmail.com 
13 Abstract

14 Background: Plasmid-mediated quinolone resistance (PMQR) has received considerable 15 attention recently. Data analysis in Jawaharlal Institute of Postgraduate Medical Education \& Research (JIPMER) revealed $75 \%$ of the Enterobacteriaceae isolates to be ciprofloxacin-resistant in 2012. Few reports regarding the prevalence of PMQR are available from India. Hence, the present study was carried out to ascertain the prevalence of PMQR genes among clinical isolates of ciprofloxacin-resistant Enterobacteriaceae in JIPMER.

Methods: The study included 642 ciprofloxacin-resistant clinical Enterobacteriaceae isolates. JIPMER hospital's annual consumption data for fluoroquinolones were retrieved from the Department of Pharmacy. The test isolates were screened for the presence of qnr $A, B, D, S$ and $a a c\left(6^{\prime}\right)-I b-c r$ genes. PMQR-positive isolates alone were tested for the presence of class I (intI1) and class II (intI2) integrons. Randomly selected PCR amplicons were sequenced and analysed using MEGA software. A total of $30 \mathrm{PMQR}$ strains chosen at random were assessed for the transferability of the PMQR genes.

Results: A majority of the strains exhibited high MIC values with 106 strains exhibiting MIC values $>256 \mu \mathrm{g} / \mathrm{mL}$. The $a a c\left(6^{\prime}\right)-I b-c r$ gene had the highest prevalence at $64 \%$ (414) while, $q n r B$ and $q n r S$ genes were present in 15\% (97) and 10\% (64) of the isolates respectively. None of the strains were positive for $q n r A$ and $q n r D$. All PMQR-positive isolates were screened for class I (intI1) and class II (intI2) integrons. Class I integron was found to be predominant among the test isolates with a few of them carrying both the classes of integrons. Transferability of PMQR genes to transconjugants was identified.

Conclusion: The incidence of PMQR genes in the tertiary-care setup of the JIPMER hospital was found to be high which could be probably due to the increased prescription of fluoroquinolones. Thus, there is a need for rational usage of fluoroquinolones. 
37

38

39

40

41

\section{Introduction}

Fluoroquinolone resistance among the Enterobacteriaceae is a serious public health problem as it is responsible for the rise in respiratory tract infections worldwide whereas, in Asia UTI and intra-abdominal infections are on the rise (Dalhoff, 2012). Accumulation of mutations within target DNA gyrase enzyme was thought be the only mechanism of fluoroquinolone resistance until in the year 1998 when $q n r$, a plasmid-borne fluoroquinolone resistance gene, was reported (Martínez-Martínez, Pascual \& Jacoby, 1998). Similarly, there are a few more reports on fluoroquinolone resistance mechanism/s that involve enzymatic modification of fluoroquinolones by $a a c\left(6^{\prime}\right)-I b-c r$ encoded Fluoroquinolone-modifying enzyme and efflux pump activities mediated by qepA \& oqxAB (Robicsek et al., 2006a; Vetting et al., 2008; Robicsek et al., 2006b; Strahilevitz et al., 2009). Of late, Enterobacteriaceae isolates have exhibited a high level of fluoroquinolone resistance (Redgrave et al., 2014). Due to the increase in fluoroquinolone resistance, plasmid-mediated quinolone resistance (PMQR) has received considerable attention in recent years. The $q n r$ gene alleles $A, B, C, D$ and $S$, encode for a pentapeptide repeat protein capable of protecting DNA gyrase from fluoroquinolones (Robicsek et al., 2006b; Strahilevitz et al., 2009). Integrons are mobile genetic elements that have been identified in plasmids harbouring PMQR genes allowing them to spread horizontally for which they are widely feared (Pazhani et al., 2011).

PMQR genes have been stressed upon in many studies (Strahilevitz et al., 2009; Pazhani et al., 2011; Mendez et al., 2009). The quinolone resistance rate in clinical isolates of gram-negative bacilli ranges from 65\% to 70\% in India (Hariharan et al., 2015; Varughese \& Beniwal, 2015). Despite such high fluoroquinolone resistance rates, fewer than ten studies from India have reported the prevalence of PMQR genes. (Pazhani et al., 2011; Geetha et al., 2014; Magesh et al., 2011; Bhattacharya et al., 2011). Data analysis in the diagnostic microbiology laboratory attached to Jawaharlal Institute of Postgraduate Medical Education \& Research (JIPMER), Puducherry, India, a teaching hospital with a bed strength of 1500 , revealed $75 \%$ of the Enterobacteriaceae isolates to be resistant to ciprofloxacin in the year 2012 (T. Yugendran, unpublished data). Therefore, in the present study ciprofloxacin-resistant isolates belonging to the family Enterobacteriaceae from the samples of patients attending JIPMER hospital were 
66 collected and screened for PMQR determinants and integrons with an aim to ascertain the PMQR 67 prevalence in the hospital. 
68

69

\section{Materials \& Methods}

The study was approved by JIPMER Institute Ethics Committee, Jawaharlal Institute of Post Graduate Medical Education and Research, Puducherry, India (ECR/324/Inst/PY/2013).

\section{Bacterial strains}

A total of 642 clinical isolates belonging to the family Enterobacteriaceae resistant to ciprofloxacin by Kirby-Bauer disc diffusion method subsequently confirmed by agar dilution MIC were part of the study. Only one positive culture per patient was included. Standard methods were followed for isolation and identification of the bacteria from clinical specimens like blood, pus, CSF, etc. (Forbes, Sahm \& Weissfeld, 2007). E. coli (J53), Shigella boydii (IDH738), E. coli (BCH1108), Morganella morganii (500914) and E. coli (TC145) harbouring $q n r A, q n r B, q n r S, q n r D \& a a c\left(6^{\prime}\right)-I b$ and $q n r A \& a a c\left(6^{\prime}\right)-I b-c r$ were used as positive controls in the PCR assay. The ATCC strain E. coli 25922 served as the quality control in the antimicrobial susceptibility test.

\section{Antibiotic Susceptibility Test}

The discs for amikacin $(30 \mu \mathrm{g})$, ceftriaxone $(30 \mu \mathrm{g})$, ceftazidime $(30 \mu \mathrm{g})$, ciprofloxacin $(5 \mu \mathrm{g})$ and gentamicin $(10 \mu \mathrm{g})$, meropenem $(10 \mu \mathrm{g})$ were prepared in-house using antibiotics in pure power form (Himedia Laboratories, India) whereas cefoperazone-sulbactam disc was procured from Microxpress Tulip Diagnostics Pvt. Ltd, India. In particular cases, bacteria were also tested for imipenem (Himedia Laboratories, India) and piperacillin-tazobactam (Microxpress Tulip Diagnostics Pvt. Ltd, India). The antibiotic susceptibility of the test isolates was interpreted as per CLSI M100-S25. Similarly, Minimum Inhibitory Concentration (MIC) values were determined according to CLSI M100-S25 guidelines for ciprofloxacin alone by agar dilution method using Muller Hinton agar procured from Himedia Laboratories, India. E. coli ATCC 25922 was included as the quality control. The lowest concentration of antibiotic at which the growth of bacteria had been completely inhibited was recorded as the MIC.

\section{Fluoroquinolone Prescribing Data}

JIPMER hospital's annual prescribing data for fluoroquinolones were retrieved from Department of Pharmacy, JIPMER. 
96

97 98

\section{PCR Assay}

DNA templates were prepared from the overnight inoculum of test strains grown on Nutrient HiVeg ${ }^{\mathrm{TM}}$ Agar (Himedia Laboratories, India) resuspended in MiliQ water after three rounds of washing. Crude template DNA was prepared by boiling lysis method (Pazhani et al., 2011). The reactions were performed in Flexilid Mastercycler PCR system (Eppendorf, Germany). The target genes, primer sequences, PCR conditions and amplified product sizes are given in Table I. PMQR-positive isolates alone were screened for the class I (intI1) and class II (intI2) integrons. Electrophoresis and staining analysed the PCR products with ethidium bromide.

\section{Nucleotide Sequencing}

Sequencing of PCR products was carried out at Xcelris Genomics, Ahmedabad. Nucleotide sequences were analysed over BLAST server (ww.ncbi.nlm.nih.gov/blast) against the GenBank database of the National Center for Biotechnology Information. The phylogeny of the randomly sequenced $a a c\left(6^{\prime}\right)-I b-c r$ amplicons were determined based on the nucleotide substitutions per site, i.e., the number of 'nucleotide substitutions' within the given sequence divided by the length of the sequence using MEGA software (Kumar, Stecher \& Tamura, 2015).

\section{Conjugation assay}

PMQR-positive strains numbering 30 (E.coli - 15, Klebsiella pneumoniae - 4, Klebsiella oxytoca - 3, Enterobacter spp. - 3, Citrobacter freundii - 3, Proteus mirabilis - 2) were randomly selected for assessing the transferability of the PMQR genes following a previously described method (Jacoby et al., 1996) with E. coli (J53) AziR (sodium azide-resistant) as the recipient strain. Transconjugants were selected on MacConkey agar containing sodium azide $(100 \mu \mathrm{g} / \mathrm{mL})$ and ciprofloxacin $(0.5 \mu \mathrm{g} / \mathrm{mL})$ and confirmed based on the results of biochemical and antimicrobial susceptibility tests carried out for transconjugants, recipient and donor bacterial cells. Screening of the transconjugants by PCR assay determined the transferability of PMQR genes. 


\section{RESULTS}

121

\section{Antibiotic Susceptibility Test}

122 Out of 642 Enterobacteriaceae isolates, 43 isolates were resistant to all the antibiotics tested.

123 Resistance to ceftriaxone, ceftazidime and cefoperazone-sulbactam were seen in 398, 381 and 124351 isolates respectively. All the isolates were resistant to ciprofloxacin. Resistance to 125 ciprofloxacin was confirmed by the agar dilution method. The MIC values against ciprofloxacin 126 ranged from $2 \mu \mathrm{g} / \mathrm{mL}$ to $>256 \mu \mathrm{g} / \mathrm{mL}$ as summarised in Fig. I. It is notable that $106(\sim 16 \%)$ 127 strains had MIC values $>256 \mu \mathrm{g} / \mathrm{mL}$. A total of 112 isolates were resistant to meropenem, and it 128 was most effective among all the tested antibiotics.

2. Fluoroquinolone Prescribing Data

130

131

132

133

134

135

136

137

Data from the Department of Pharmacy revealed that ciprofloxacin is the most extensively used fluoroquinolone for various infections in JIPMER hospital followed by levofloxacin and ofloxacin (supplementary data, S1).

\section{PMQR Prevalence}

Remarkably, out of the 642 strains, as many as 414 (64.5\%) harboured aac(6')-Ib-cr. The qnrB and $q n r S$ genes were present in 97 (15\%) and 64 (10\%) isolates respectively. None of the strains were positive for $q n r A \& q n r D$, indicating the absence of these $q n r$ alleles among the clinical isolates included in the study (Fig - II). The proportion of $a a c\left(6^{\prime}\right)-I b-c r, q n r B$ and $q n r S$ among the clinical isolates was found to be $64.49,15.1$ and 9.96 respectively. The overall prevalence of $a a c\left(6^{\prime}\right)-I b-c r, q n r B$ and $q n r S$ genes among the clinical Enterobacteriaceae strains isolated from JIPMER hospital could probably fall in the range of $60.72-68.12,12.5-18.04$ and $7.82-12.47$ respectively.

E. coli had the maximum frequency of aac(6')-Ib-cr (197) and $q n r B$ (43) genes. E. coli constituted almost half of the total $a a c\left(6^{\prime}\right)-I b-c r$ positive isolates. On the other hand, the frequency of the qnrS gene was highest among K. pneumoniae isolates (32) with Klebsiella spp. altogether accounting for more than half of the total qnrS gene identified (47). The most interesting fact was that PMQR genes were more predominant among E. coli, Klebsiella spp., and Enterobacter spp. The occurrence of qnr alleles among Citrobacter spp., Serratia spp., 
148 Proteus mirabilis and Providencia spp. were almost negligible with Proteus mirabilis alone 149 carrying the $q n r B$ allele (Fig. - III). Remarkably, of the 106 test isolates with MIC $>256 \mu \mathrm{g} / \mathrm{mL}$ 150 only, three isolates were negative for PMQR genes.

151 The majority of the strains were found to carry one of the PMQR genes. But 7\% of the isolates 152 were found positive for multiple PMQR genes. All these isolates carried either qnrB or qnrS 153 along with the $a a c\left(6^{\prime}\right)-I b-c r$ gene. None of the isolates harboured $q n r B$ and $q n r S$ simultaneously. 154 E. coli, Klebsiella spp., Enterobacter spp. and Proteus mirabilis were the organisms carrying 155 multiple PMQR genes but, the association of $q n r S$ with aac(6')-Ib-cr was seen only in E. coli 156 and $K$. pneumoniae. The presence of $a a c\left(6^{\prime}\right)-I b-c r$ and $q n r S$ genes were associated with high 157 MIC values $(\geq 64 \mu \mathrm{g} / \mathrm{mL})$ and these associations were statistically significant with p-values $158<0.0000001$ and $<0.006261$ respectively.

159 Out of 528 PMQR positive isolates 212 were found to carry class I integron whereas, 95 isolates 160 were found to carry class 2 integron and 47 isolates were positive for both the classes of 161 integrons. However, we must admit that the study neither included the integron sequence 162 analysis nor screened the integron-positive isolates for the presence of contiguous resistance 163 gene cassettes.

4. Transfer of PMQR

165

166

167

168

169

170

171

172

173

174

175

Of the 30 PMQR positive strains included in the conjugation only 18 transconjugants were successfully achieved. Among the transconjugants 11 were positive for $a a c\left(6^{\prime}\right)-I b-c r$, four were positive for $q n r B$, and two were positive for $q n r S$ genes. It is interesting to note that one particular transconjugant was found positive for both $a a c\left(6^{\prime}\right)-I b-c r$ and $q n r B$.

\section{Nucleotide sequencing}

A total of $25 a a c\left(6^{\prime}\right) I b-c r$, seven $q n r B$ and four $q n r S$ strains were sequenced but none them had novel mutations within the nucleotide sequence. We have submitted nucleotide sequences of 10 $a a c\left(6^{\prime}\right) I b-c r$, two $q n r B$ and one $q n r S$ genes to GenBank and accession numbers assigned are: KR080534 to KR080543 for $a a c\left(6^{\prime}\right)-I b-c r$, KR080544 \& KR080545 for qnrB and KR080546 for $q n r S$. All the identified PMQR genes were found to be closely related based on the pair-wise distance matrix value. The overall distance matrix for $a a c\left(6^{\prime}\right)-I b-c r$ was found to be 2.642 
176 whereas the pair-wise distance matrix for the $q n r B$ gene sequences was found out be 1.255 . The

177 study did not attempt to identify variants of $q n r$ genes. The pair-wise distance matrix of the $178 a a c\left(6^{\prime}\right)-I b-c r$ gene has been summarised as percentages, i.e., the number of nucleotide 179 substitution per 100 nucleotide in the supplementary data S2.

\section{DISCUSSION}

181 The preceding decade has witnessed a very high usage of fluoroquinolones (Geetha et al., 2014).

182 This extensive usage of fluoroquinolones has led to the emergence of Enterobacteriaceae isolates 183 with reduced susceptibility to them. Interestingly, neither the fluoroquinolone prescription in the 184 hospital nor the frequency of PMQR isolates varied much in the four years of the study (Fig. IV).

185 In Enterobacteriaceae, the three major groups of $q n r$ determinants are $q n r A$, $q n r B$ and $q n r S$ 186 (Geetha et al., 2014) with qnrD having a prevalence of negligible extent. The $q n r C$ gene was not 187 included in this study as it has got the least prevalence (Kim et al., 2009).

188 The sample sizes of the previous studies from India concerning the prevalence of PMQR genes 189 among Enterobacteriaceae ranged between 20 and 100 (Pazhani et al., 2011; Geetha et al., 2014; 190 Magesh et al., 2011; Bhattacharya et al., 2011). We have reported the prevalence of PMQR 191 determinants from a sample size of 642 ciprofloxacin-resistant Enterobacteriaceae clinical 192 isolate, making our report the largest study of its kind so far in India.

193 A high prevalence of resistance among Enterobacteriaceae against fluoroquinolones particularly 194 ciprofloxacin has been demonstrated in this study similar to previous reports from all over the 195 world. However, there are few striking differences. Firstly, a variety of Enterobacteriaceae 196 species were included in this study [Fig. - III], compared to the previous reports that are mostly 197 limited to E. coli and Klebsiella pneumoniae with rare inclusions of Proteus spp. and 198 Enterobacter spp. (Veldman et al., 2011; Wang et al., 2003; Pasom et al., 2013; Yang et al., 199 2014). This study reports the presence of PMQR in Providencia rettgeri for the first time. 200 Secondly, the proportion of aac(6')-Ib-cr genes among our isolates was found to be high. The 201 prevalence of $a a c\left(6^{\prime}\right)-I b-c r$ in previously published reports ranged between $7 \%$ to $40 \%$ (Wang et 202 al., 2003; Pasom et al., 2013; Veldman et al., 2011) however the prevalence rate of the same 203 gene in our study was found to be $64.5 \%$. The first PMQR gene to be identified and reported was 204 qnrA (Strahilevitz et al., 2009) but, this allele was found to be absent among our clinical strains. 
205 It is remarkable to note that all the E. coli resistant to ciprofloxacin were found to carry one or

206 the other PMQR gene. This is worrisome because PMQR genes are capable of horizontal transfer

207 thereby accelerating the spread of this resistance mechanism among various clinical pathogens.

208 It is known that QRDR mutations induce high-level MICs while, PMQR genes induce low-level 209 MICs (Strahilevitz et al., 2009; Robicsek et al., 2006b). However, of the 528 PMQR-positive test 210 isolates found in this study, $329(62.2 \%)$ had MICs $\geq 64 \mu \mathrm{g} / \mathrm{mL}$, while only 19 (16.5\%) of the 211114 isolates lacking a PMQR gene had MICs $\geq 64 \mu \mathrm{g} / \mathrm{mL}(\mathrm{p}<0.0001)$. Therefore, there was a 212 significant association between increased MIC and the presence of PMQR genes, opening up the 213 possibility that PMQR genes could have contributed to high MICs among the test isolates. But, 214 we must agree that the efflux pump activities of these test isolates were not elucidated and their 215 QRDR mutation profile was also not identified. Thus, this particular finding of the study is 216 inconclusive as to how far PMQR genes have contributed to the increase in MIC of a strain 217 against ciprofloxacin. With future investigation of these clinical isolates for QRDR mutations 218 and efflux mechanisms, the prominence of PMQR in fluoroquinolone resistance can be 219 elucidated.

\section{CONCLUSION}

221

222

223

224

225

226

227

228

229

230

231

In the present study, we have elucidated the prevalence of the plasmid-mediated quinolone resistance genes among clinical Enterobacteriaceae isolates recovered from a tertiary care hospital in Puducherry, India. Resistance to fluoroquinolones has predominantly increased with a majority of the isolates exhibiting high MIC values. Therefore, to combat this increased fluoroquinolone resistance it would be appropriate to use fluoroquinolones rationally for treating gram-negative infections. However, the significant finding of our study is that the prevalence of PMQR genes in JIPMER hospital is very high.

Moreover, the majority of the literatures on $q n r$ gene are on prevalence rates from around the world and reports on mechanistic aspects at the molecular level are very few. Future research should focus more the molecular mechanism of the PMQR genes and its encoded proteins.

\section{Acknowledgements}


232 Authors thank Dr. G.A. Jacoby, Lahey Clinic for providing us the E. coli strain J53 and Dr. T.

233 Ramamurthy, Translational Health Science and Technology Institute for providing E. coli (J53),

234 Shigella boydii (IDH738), E. coli (BCH1108), Morganella morganii (500914) and E. coli

235 (TC145) harbouring qnrA, qnrB, qnrS, qnrD \& aac(6')-Ib and qnrA \& aac(6')-Ib-cr genes 236 respectively.

\section{References:}

238 Axel Dalhoff. 2012. Global fluoroquinolone resistance epidemiology and implictions for 239 clinical use. Interdisciplinary Perspectives on Infectious Diseases 2012:1-37. 240 DOI: $10.1155 / 2012 / 976273$

241 Martínez-Martínez L, Pascual A, Jacoby GA. 1998. Quinolone resistance from a transferable 242 plasmid. Lancet 351: 797-799.

Strahilevitz J, Jacoby GA, Hooper DC, Robicsek A. 2009. Plasmid-Mediated Quinolone Resistance: a Multifaceted Threat. Clinical Microbiology Reviews 22: 664-689. DOI:10.1128/CMR.00016-09

Robicsek A, Strhilevitz J, Jacoby GA, Macielag M, Abbanat D, Park Ch, Bush K, Hooper DC. 2006. Fluoroquinolonee-modifying enzyme: a new adaptation of a common aminoglycoside acetyltransferase. Nature Medicine 12:83-88. DOI:10.1038/nm1347

Vetting MW, Park CH, Hegde SS, Jacoby GA, Hooper DC, Blanchard JS. 2008. Mechanistic and structural analysis of aminoglycoside Nacetyltransferase aac( $\left(6^{\prime}\right)-\mathrm{Ib}$ and its bifunctional, fluoroquinolone-active $\quad \operatorname{aac}\left(6^{\prime}\right)-\mathrm{Ib}-\mathrm{cr} \quad$ variant. Biochemistry $\quad 47$ : 9825-9835. DOI:10.1021/bi800664x.

Robicsek A, Jacoby GA, Hooper DC. 2006. The worldwide emergence of plasmid-mediated quinolone resistance. The Lancet Infectious Diseases 6:629-640. DOI:10.1016/S14733099(06)70599-0 
259

260

261

262

263

264

265

266

267

268

269

270

271

272

273

274

275

276

277

278

279

280

281

282

Pazhani GP, Chakraborty S, Fujihara K, Yamasaki S, Ghosh A, Nair GB, Ramamurthy T. 2011. QRDR mutations, efflux system \& antimicrobial resistance genes in enterotoxigenic Escherichia coli isolated from an outbrek of diarrhoea in Ahmedabad, India. Indian Journal of Medical Research 134:214-223.

Mendez AE, Pitart C, Ruiz J, Marco F, Gascon J, Villa J. 2009. Evolution of antimicrobial resistance in enteroaggregative Escherichia coli causing traveller's diarrhoea. Journal of Antimicrobial Chemotherapy 64: 343-347. DOI: 10.1093/jac/dkp178

Geetha VK, Yugendran T, Srinivasan R, Harish BN. 2014. Plasmid-mediated quinolone resistance in typhoidal Salmonellae: A preliminary report from South India. Indian Journal of Medical Microbiology 32: 31-34. DOI: 10.4103/0255-0857.124292.

Magesh H, Kamatchi C, Vaidyanathan R, Sumathi G. 2011. Identification of plasmidmediated quinolone resistance genes qnrA1, qnrB1 and aac(6')-1b-cr in a multiple drugresistant isolate of Klebsiella pneumoniae from Chennai. Indian Journal of Medical Microbiology 29: 262-268. DOI: 10.4103/0255-0857.83910.

Bhattacharya D, Bhattacharjee H, Thamizhmani R, Sayi DS, Bharadwaj AP, Singhania M, Sugunan AP, Roy S. 2011. Prevalence of the plasmid-mediated quinolone resistance determinants among clinical isolates of Shigella sp. in Andaman \& Nicobar Islands, India. Letters in Applied Microbiology 53: 247-251. DOI: 10.1111/j.1472-765X.2011.03092.x. Epub 2011 Jun 27.

Hariharan P, Bharani T, Franklyne JS, Biswas P, Solanki SS, Paul-Satyaseela M. 2015. Antibiotic susceptibility pattern of Enterobacteriaceae and non-fermenter Gram-negative clinical isolates of microbial resource orchid. Journal of Natural Science, Biology and Medicine 6:198-201. DOI:10.4103/0976-9668.149121

Varughese LR, Beniwal B. 2015. High quinolone resistance pattern among enteric pathogens isolated from patients with urinary tract infection. Indian Journal of Biotechnology 14:167171.

Forbes BA, Sahm DF, Weissfeld AS. 2007. Bailey \& Scott's Diagnostic Microbiology. Missouri: Elsevier Mosby. 
287

Ciesielczuk H, Hornsey M, Choi V, Woodford N, Wareham DW. 2013. Development and evaluation of a multiplex PCR for eight plasmid-mediated quinolone-resistance determinants. Journal of Medical Microbiology 62: 1823-1827. DOI:10.1099/jmm.0.064428-0.

Cavaco LM, Hasman H, Xia S, Aarestrup FM. 2009. qnrD, a Novel Gene Conferring Transferable Quinolone Resistance in Salmonella enterica Serovar Kentucky and Bovismorbificans Strains of Human Origin. Antimicrobial Agents and Chemotherapy 53: 603-608. DOI: 10.1128/AAC.00997-08

Cattoir V, Poirel L, Rotimi V, Claude-James S, Nordmann P. 2007. Multiplex PCR for detection of plasmid-mediated quinolone resistance $q n r$ genes in ESBL-producing enterobacterial isolates. Journal of Antimicrobial Chemotherapy 60:394-397. doi: 10.1093/jac/dkm204

Wareham DW, Umoren I, Khanna P, Gordon NC. 2010. Allele-specific polymerase chain reaction (PCR) for rapid detection of the aac(6')-Ib-cr quinolone resistance gene. International Journal of Antimicrobial Agents 36: 476-477. doi: 10.1016/j.ijantimicag.2010.07.012.

Jacoby GA, Han P. 1996. Detection of Extended-Spectrum b-Lactamases in Clinical Isolates of Klebsiella pneumoniae and Escherichia coli. Journal of Clinical Microbiology. 34:908911.

Kim HB, Park CH, Kim CJ, Kim EC, Jacoby GA, Hooper DC. 2009. Prevalence of PlasmidMediated Quinolone Resistance Determinants over a 9-Year Period. Antimicrobial Agents and Chemotherapy 53: 639-645. doi:10.1128/AAC.01051-08

Kumar S, Stecher G, Tamura K. 2015. MEGA7: Molecular evolutionary genetics analysis version 7.0 for bigger datasets. Molecular Biology and Evolution (submitted). http://www.megasoftware.net

Veldman K, Cavaco LM, Mevius D, Battisti A, Franco A, Botteldoorn N, Bruneau M, Perrin-Guyomard A, Cerny T, Escobar CDF, Guerra B, Schroeter A, Gutierrez M, Hopkins K, Myllyniemi AL, Sunde M, Wasyl D, Aarestrup FMal. 2011. International collaborative study on the occurrence of plasmid-mediated quinolone resistance in Salmonella enterica and 
315 Escherichia coli isolated from animals, humans, food and the environment in 13 European 316 countries. Journal of Antimicrobial Chemotherapy 66:1278-1286. doi: 10.1093/jac/dkr084

317 Wang M, Tran JH, Jacoby GA, Zhang Y, Wang F, Hooper DC. 2003. Plasmid-Mediated 318 Quinolone Resistance in Clinical Isolates of Escherichia coli from Shanghai, China. Journal 319 of Antimicrobial Chemotherapy 47: 2242-2248. DOI: 10.1128/AAC.47.7.2242-2248.2003

320 Pasom W, Chanawong A, Lulitanond A, Wilailuckana C, Kenprom S, Puang-Ngern P. 2013. 321 Plasmid-mediated quinolone resistance genes, aac(6')-Ib-cr, $q n r \mathrm{~S}, q n r \mathrm{~B}$, and $q n r \mathrm{~A}$, in urinary 322 isolates of Escherichia coli and Klebsiella pneumoniae at a teaching hospital, Thailand. 323 Japanese Journal of Infectious Diseases 66:428-432. http://doi.org/10.7883/yoken.66.428

324 Yang HY, Nam YS, Lee HJ. 2014. Prevalence of plasmid-mediated quinolone resistance 325 genes among ciprofloxacin-nonsusceptible Escherichia coli and Klebsiella pneumoniae 326 isolated from blood cultures in Korea. Canadian Journal of Infectious Diseases and Medical 327 Microbiology 25:163-169. 


\section{Table 1 (on next page)}

Table_I

List of the primer-pairs used in this study. 


\begin{tabular}{|c|c|c|c|c|c|c|}
\hline \multirow[t]{2}{*}{ Gene } & \multirow{2}{*}{\multicolumn{2}{|c|}{ Primer Sequence (5'-3') }} & \multirow{2}{*}{$\begin{array}{c}\text { Amplicon } \\
\text { Size } \\
\text { (bp) }\end{array}$} & \multirow[t]{2}{*}{ Reference } & \multicolumn{2}{|c|}{$\begin{array}{c}\text { PCR } \\
\text { Condition }\end{array}$} \\
\hline & & & & & $\mathrm{T}^{\dagger}$ & $\mathrm{T}^{*}$ \\
\hline \multirow[t]{2}{*}{ qnrA } & Forward & CAGCAAGAGGATTTCTCACG & \multirow[t]{2}{*}{630} & \multirow{2}{*}{$\begin{array}{l}\text { Ciesielczuk et } \\
\text { al., (2013) }\end{array}$} & \multirow[t]{2}{*}{58} & \multirow[t]{2}{*}{30} \\
\hline & Reverse & AATCCGGCAGCACTATTACTC & & & & \\
\hline \multirow[t]{2}{*}{$q n r B$} & Forward & GGCTGTCAGTTCTATGATCG & \multirow[t]{2}{*}{488} & \multirow{2}{*}{$\begin{array}{c}\text { Ciesielczuk et } \\
\text { al., (2013) }\end{array}$} & \multirow[t]{2}{*}{59.1} & \multirow[t]{2}{*}{30} \\
\hline & Reverse & SAKCAACGATGCCTGGTAG & & & & \\
\hline \multirow[t]{2}{*}{$q n r D$} & Forward & CGAGATCAATTTACGGGGAATA & \multirow[t]{2}{*}{581} & \multirow{2}{*}{$\begin{array}{l}\text { Cavaco et al., } \\
\text { (2009) }\end{array}$} & \multirow[t]{2}{*}{57} & \multirow[t]{2}{*}{30} \\
\hline & Reverse & AACAAGCTGAAGCGCCTG & & & & \\
\hline \multirow[t]{2}{*}{$q n r S$} & Forward & GCAAGTTCATTGAACAGGGT & \multirow[t]{2}{*}{428} & \multirow{2}{*}{$\begin{array}{c}\text { Cattoir et al., } \\
\text { (2007) }\end{array}$} & \multirow[t]{2}{*}{55.6} & \multirow[t]{2}{*}{30} \\
\hline & Reverse & TCTAAACCGTCGAGTTCGGCG & & & & \\
\hline \multirow[t]{2}{*}{$a a c\left(6^{\prime}\right)-I b-c r$} & Forward & TTGGAAGCGGGGACGGAM & \multirow[t]{2}{*}{260} & \multirow{2}{*}{$\begin{array}{l}\text { Wareham et al., } \\
\qquad(2010)\end{array}$} & \multirow[t]{2}{*}{58} & \multirow[t]{2}{*}{30} \\
\hline & Reverse & ACACGGCTGGACCATA & & & & \\
\hline \multirow[t]{2}{*}{ intII } & Forward & GTTCGGTCAAGGTTCTG & \multirow[t]{2}{*}{920} & \multirow{2}{*}{$\begin{array}{c}\text { Pazhani et al., } \\
\text { (2011) }\end{array}$} & \multirow[t]{2}{*}{55} & \multirow[t]{2}{*}{45} \\
\hline & Reverse & GCCAACTTTCAGCACATG & & & & \\
\hline \multirow[t]{2}{*}{ intI2 } & Forward & ATGTCTAACAGTCCATTTTT & \multirow[t]{2}{*}{420} & \multirow{2}{*}{$\begin{array}{c}\text { Pazhani et al., } \\
\text { (2011) }\end{array}$} & 55 & 30 \\
\hline & Reverse & AAATCTTTAACCCGCAAAC & & & & \\
\hline
\end{tabular}

1

$2 \quad{ }^{\dagger}$ annealing temperature in ${ }^{\circ} \mathrm{C}$; ${ }^{\ddagger}$ extension time in sec 
1

Figure_I

Distribution of Minimum Inhibitory Concentration (MIC) of the test isolates against ciprofloxacin.

\section{CiprofloxacinMIC Distribution}

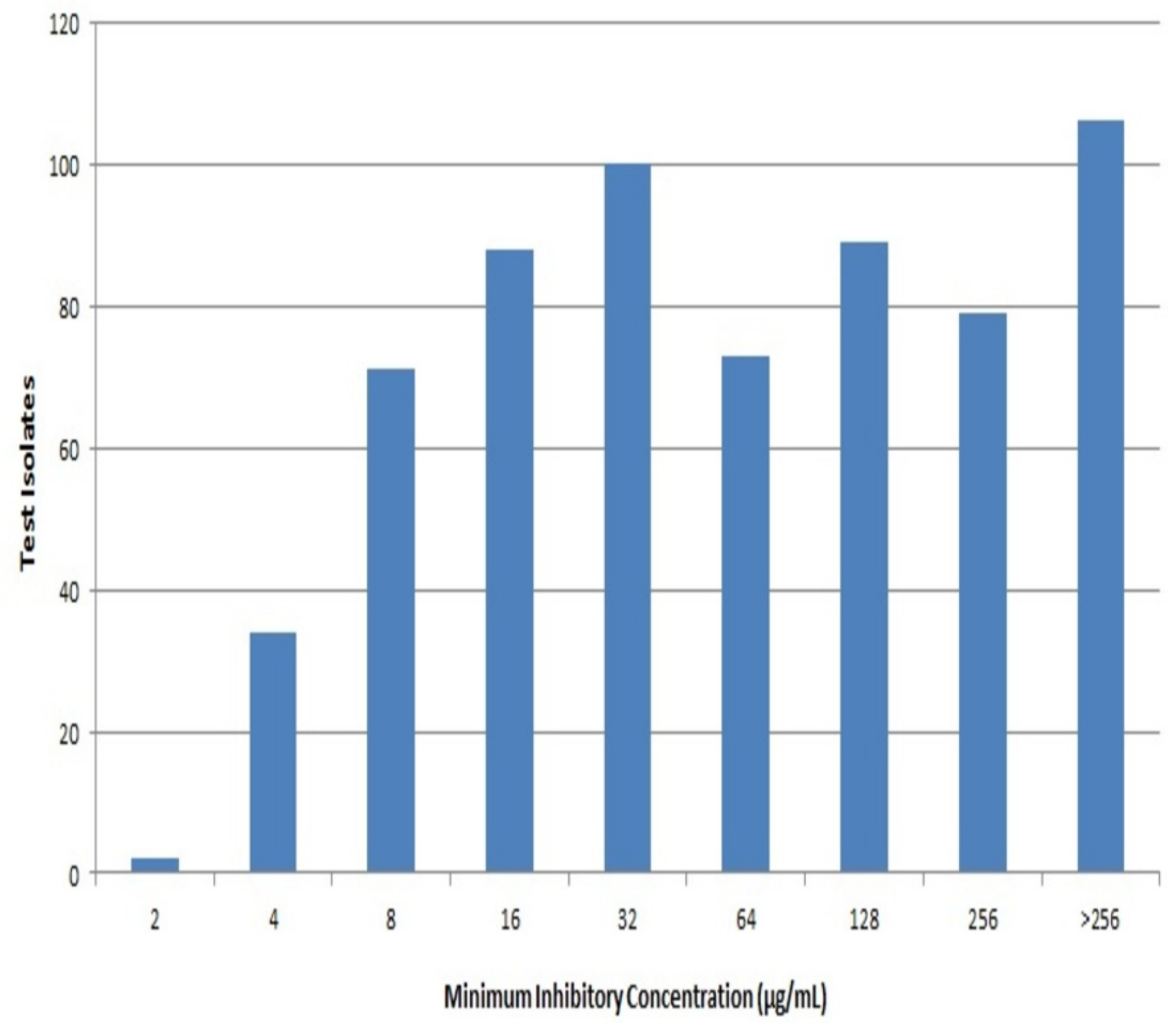


2

Figure_II

Graphical representation of the prevalence of PMQR genes identified among the test isolates.

PMQR GENE PREVALENCE

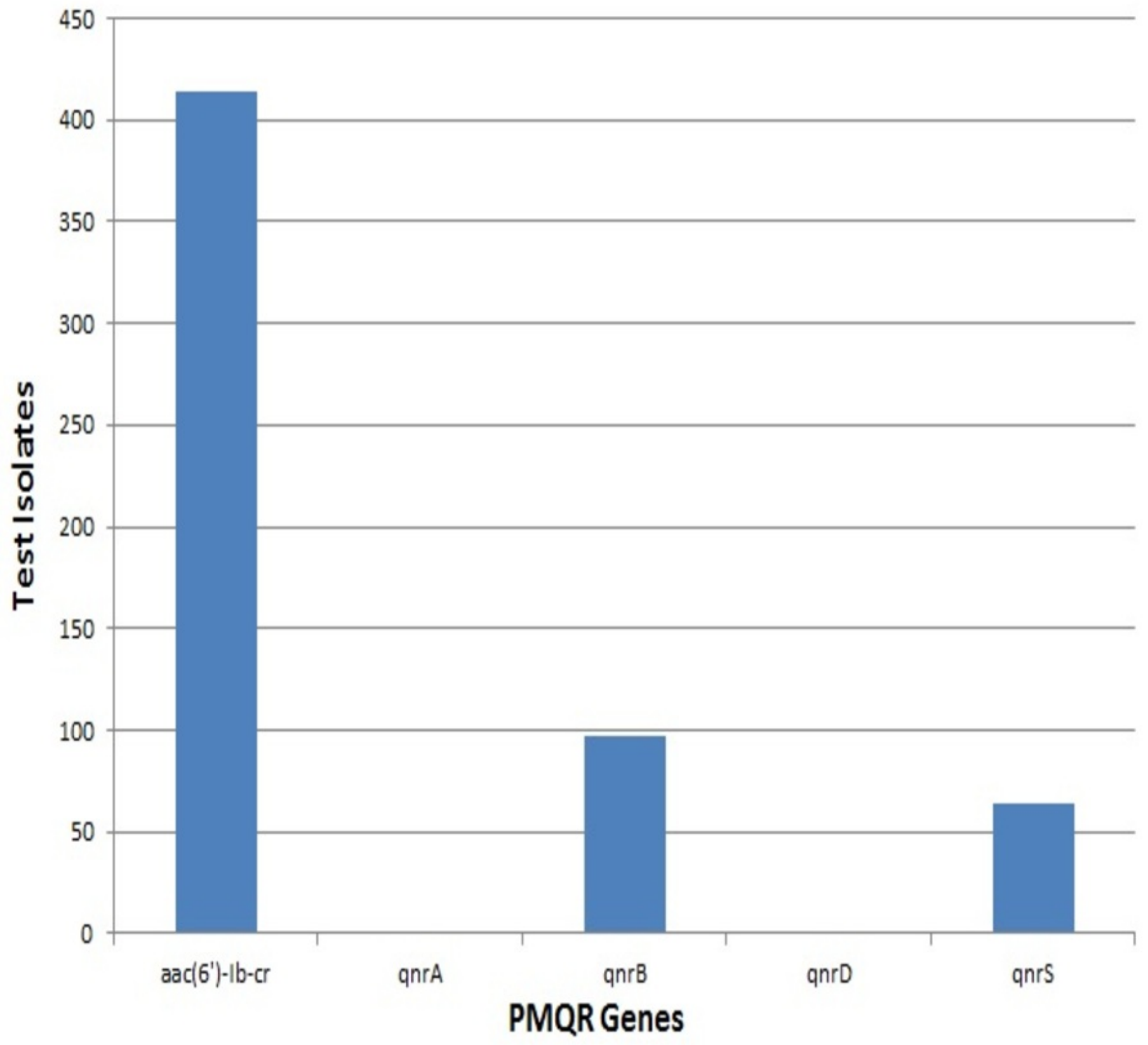


3

Figure_III

Prevalence pattern of the identified PMQR genes across Enterobacteriaceae species among the test isolates. 


\section{PMQR Gene Distribution}

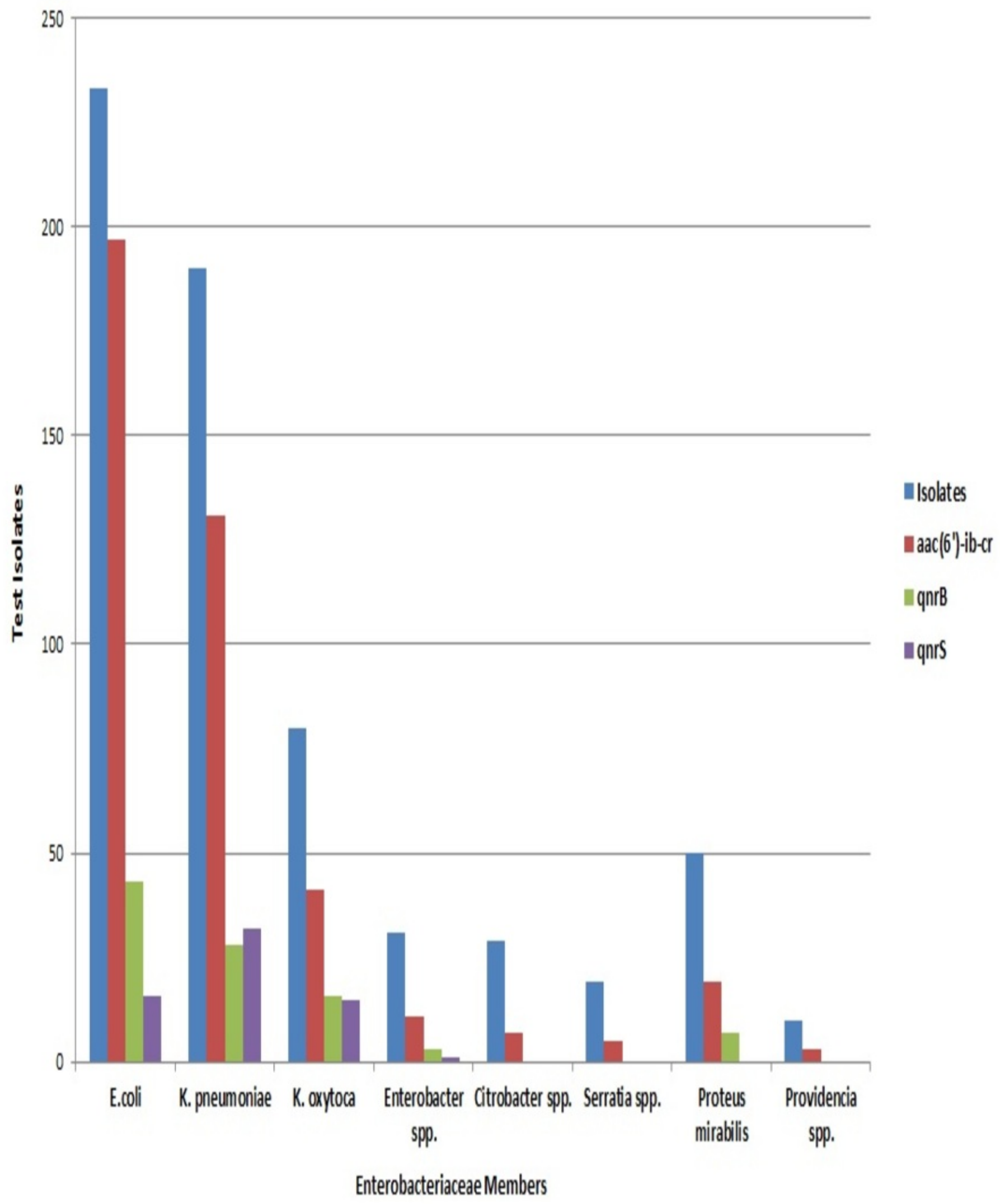


4

Figure_IV

Graphical representation of the PMQR isolate annual frequency against ciprofoxacin tablets (500 mg) annual prescription in JIPMER hospital for consecutive four years.

\section{Annual Fluoroquinolone Prescription \& PMQR Isolation}

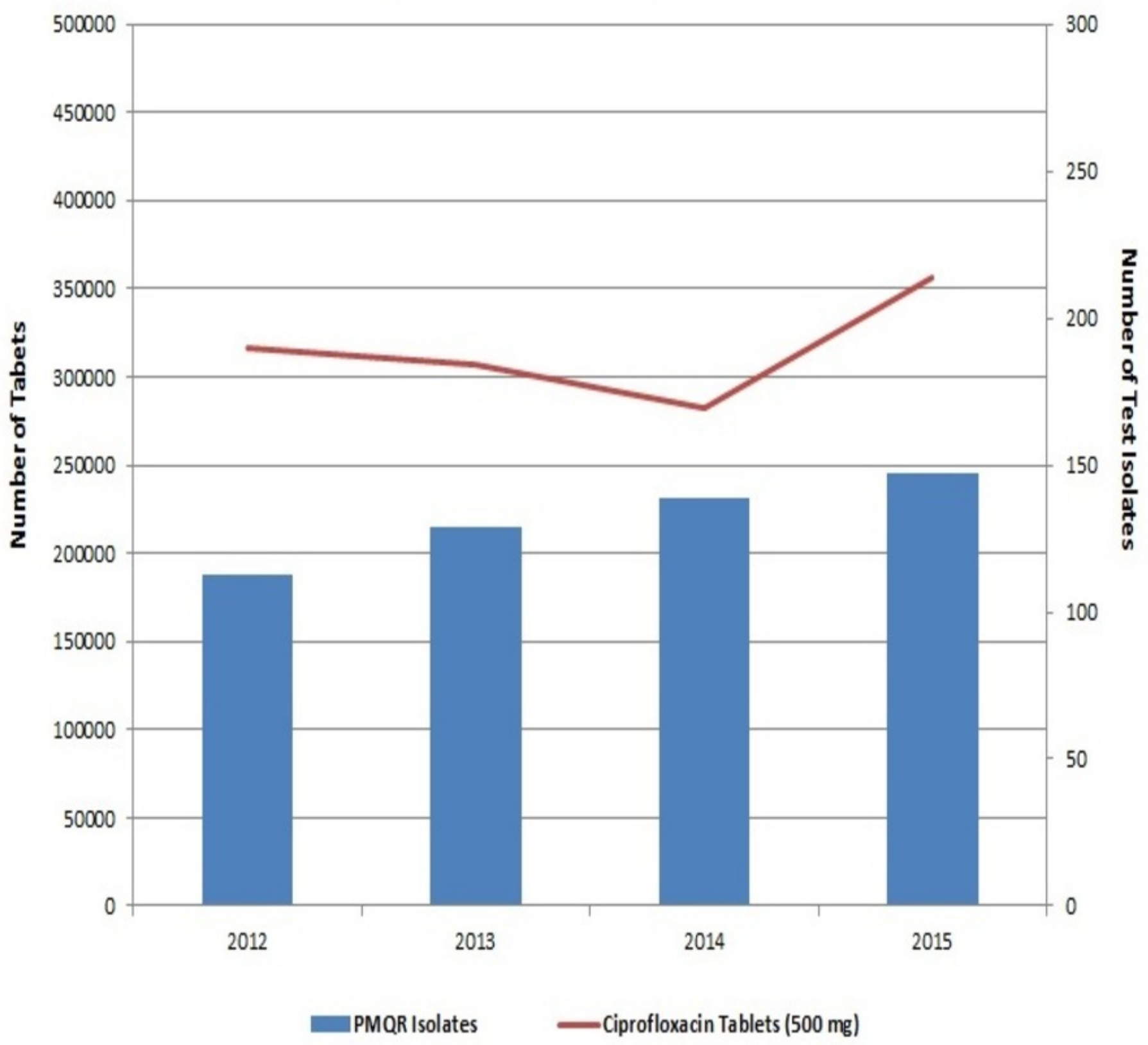

